\title{
Timed reading activity for developing EFL students' reading skills in mixed-ability classes \\ EFL students' \\ reading skills
}

\author{
Abduljalil Nasr Hazaea \\ Department of English, Najran University, Najran, Saudi Arabia and \\ Sana'a University, Sana'a, Yemen, and \\ Sultan Saleh Ahmed Almekhlafy \\ Department of English, Najran University, Najran, Saudi Arabia
}

\begin{abstract}
Purpose-Students of mixed-ability learning together in one class is a challenge for all educators, especially in English as foreign language (EFL) contexts. Timed reading activity (TRA) is an activity that can help educators address the learning needs of students in such a context. The present study investigated the effectiveness of the TRA in enhancing EFL students' reading rate and reading comprehension as well as in making them aware of potentially wrong reading strategies that they may be using.

Design/methodology/approach - A classroom intervention was designed for a group of preparatory year (PY) students at a Saudi university. The study sample consisted of one intact class of 29 students. Data were collected from pre- and post-tests of students' reading rate and reading comprehension as well as progress charts. In addition, a questionnaire was used to identify the reading strategies used by the students.

Findings - The results showed that the TRA generally enhanced the reading comprehension and the reading rate of EFL mixed-ability students as well as raised their awareness of their use of wrong fast reading strategies. Originality/value - The results of the study support the use of TRA as a remedial reading activity in EFL mixed-ability classes.
\end{abstract}

Keywords Mixed-ability students, Fast reading, Reading comprehension, Reading rate, Academic reading Paper type Research paper

\section{Introduction}

Mixed-ability classes where students of a wide range of English proficiency attend the same class, is considered a challenge for educators and instructors in English as foreign language (EFL) contexts (Al-Subaiei, 2017; Bolli, Renold, \& Wörter, 2018; Khamdamovna \& Karimovna, 2020; Naddafi, Vosoughi, \& Kowsary, 2019; Wróblewski \& Majerová, 2019; Zakarneh, Al-Ramahi, \& Mahmoud, 2020). The problem is manageable when only some students are more proficient than others in the class. But the situation becomes complex and unmanageable when most students have different levels of proficiency, learning ability and pace. In mixed-ability classes the higher-level students tend to dominate and deprive low-proficiency students of the possibility for full participation (Harmer, 2015; Scrivener, 2012). However, every student has the right to learn according to his/her abilities and learning pace.

According to Al-Shammakhi and Al-Hamadi (2015), in order to ensure all students in a mixed-ability class attain the required reading skills, educators try to find strategies that

(C) Abduljalil Nasr Hazaea and Sultan Saleh Ahmed Almekhlafy. Published in Learning and Teaching in Higher Education: Gulf Perspectives. Published by Emerald Publishing Limited. This article is published under the Creative Commons Attribution (CC BY 4.0) licence. Anyone may reproduce, distribute, translate and create derivative works of this article (for both commercial and non-commercial purposes), subject to full attribution to the original publication and authors. The full terms of this licence may be seen at http://creativecommons.org/licences/by/4.0/legalcode.

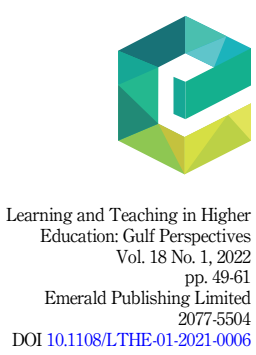

Received 25 January 2021

Revised 19 May 2021

13 November 2021

5 December 2021

9 December 2021

Accepted 12 December 2021

49

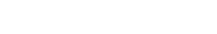

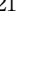


LTHE 18,1

effectively help all students. However, in reality, students rarely achieve equal participation in classroom activities and tasks. Rather, most of the activities could result in poor performance by lower level students and further widen the gap among students in mixed-ability classes.

At Saudi universities, English classes in the first common year which is known as the preparatory year (PY), contain mixed-ability students (Almekhlafy, 2017; Al-Shehri, 2017). English instructors in the PY need to manage the huge gap among students in a class, which increases the complexity of the teaching and learning process. In order to help the students develop their reading comprehension and speed, instructors must cater for a wide range of reading ability levels and implement activities that ensure equal participation from all students (Cheng, 2014). Such activities should be learner-centered and allow students to learn at their individual learning pace (Naddafi et al., 2019).

Timed reading activity (TRA) is a learner-centered activity that gives students the chance to learn at their own pace and assess their own progress (Hamersly, 2015). TRA may be useful in helping students in mixed-ability classes develop their reading skills. Moreover, by incorporating the TRA in EFL reading instruction, Saudi students could acquire reading strategies, improve their reading speed and comprehension, and enjoy reading English texts.

This study aimed to measure the effectiveness of the TRA in improving Saudi EFL students' reading rate and reading comprehension. Given the importance of English in the Saudi Higher Education context (Debbabi, Alsheyokh, Al Kous, Maimoun, Humiedan, \& Mansoor, 2019), the findings of this study could provide useful teaching strategies for mixed-ability classes.

\section{Literature review}

\section{Mixed-ability classes in EFL contexts}

Different researchers define the term "mixed-ability classes" based on students' proficiency level, skill level, learning style and/or pace. Some educators define mixed-ability classes as multilevel or heterogeneous (Al-Shammakhi \& Al-Humaidi, 2015; Yunusova, 2019; Zakarneh et al., 2020). Zakarneh et al. (2020) stated that a mixed-ability class is a place where a fluent student sits next to one who can barely piece together a sentence. Similarly, Mathews-Aydinli and Van Horne (2006) defined mixed-ability classes as classes of heterogeneous students who are placed together. Another view is that all classes encompass students with different levels, but when these differences are wide, the mixed-ability classes become more challenging for educators (Zakarneh et al., 2020). Valentic (2005) described EFL students in mixed-ability classes as different in their level of language skills, fluency, accuracy work, grammatical knowledge, size of vocabulary and command of pronunciation. Furthermore, Yunusova (2019) illustrated that mixed-ability classes do not only just encompass learners with different levels, but also learners with different learning strategies and pace. The current study operationalizes mixed-ability classes as EFL classes where students differ in their reading rate, reading comprehension and learning pace.

Mixed-ability EFL classes present several challenges for educators (Yunusova, 2019). It is hard to implement a teaching strategy that fits all students (Benmassoud \& El Madani, 2019). Mixed-ability classes require sophisticated preparation on the part of the instructor (Wróblewski \& Majerová, 2019). Furthermore, Khamdamovna and Karimovna (2020) added that time management is another challenge for the instructor and many students cannot be guaranteed full classroom participation and equal output opportunities. Because of these challenges, students in mixed-ability classes should be given the chance to control their learning to ensure better participation and outcomes. Therefore, the activities and tasks should be learner-centered to stimulate students' individual involvement and self-learning (Zakarneh et al., 2020). Without adequate and timely intervention to address these challenges, the gaps among different ability students can become unmanageable.

Many researchers recommended specific strategies and activities to overcome the challenge of mixed-ability classes in the EFL context. For example, Wright (2012) recommended that 
teachers need to create a positive and relaxed atmosphere in mixed-ability classes. Another recommendation is to encourage students' engagement in autonomous learning to help them develop the appropriate learning strategies they need to succeed in (Tomlinson, 2014). Other recommendations include employing multilevel teaching strategies and methods (Butterworth, 2010), using activities that are tailored to students' various levels (McMillan \& Joyce, 2011) and encouraging collaborative learning and learner-based activities (Hernandez, 2012). Therefore, using activities that are learner-centered and allow students to learn at their own pace and assess their own progress can help deal with mixed-ability classes (Treko, 2013).
EFL students' reading skills

\section{Timed reading activity (TRA)}

The TRA has features that can promote learning in a mixed-ability EFL class (Chang, 2010). Suk (2017) illustrated that the TRA contributed to the development of students' reading level and led to autonomous learning and fluency. The TRA increases students' responsibility in their learning process because it provides individual EFL learners a chance to do the reading task without any help from the instructor or peers, which encourages self-learning. Hamersly (2015) pointed out that the TRA exposed EFL learners to easy and various reading materials that enhanced autonomous learning. Moreover, the TRA allows students to self-evaluate their reading and demonstrate the growth they have made over the period of the activity, which in turn increases learner autonomy and promotes EFL students' motivation to read. This feature, also, facilitates the difficult process of evaluation of the activities that take place in the mixedability classes (Treko, 2013). Therefore, the TRA seems to be the appropriate type of activity for the current study context, because it can develop the ability of Saudi EFL students to read English texts comfortably at a reasonable reading rate (McLean \& Rouault, 2017; Suk, 2017).

However, it seems that the TRA has not been widely used especially in EFL contexts because of certain challenges (Suk, 2017). For many teachers and students in the EFL context, reading speed is not an important reading goal (Debbabi et al., 2019). Another reason is that many EFL educators oppose the shifting power model from the instructor to the learner and from controlled learning to self-learning and self-evaluation (Al-Mekhlafi \& Nagaratnam, 2012). Educators in EFL contexts should acknowledge these challenges before implementing the TRA as a tool to help EFL learners with heterogeneous levels in reading rate, comprehension and motivation.

By and large, TRA studies conducted in the EFL context produced positive results. Devana and Agustina (2019) found that screen text increased the reading rate of Indonesian EFL students, while Mahdizadeh and Aminafshar (2018) found that the TRA had improved the reading speed of the Iranian EFL students. Similarly, Debbabi et al. (2019) found that the TRA had a positive effect on Saudi EFL students' reading speed. In a series of studies with Taiwanese learners, Chang (2010), Chang (2012) and Chang and Millett (2015) found that the TRA significantly increased students' reading speed. Similarly, ESL students in America in Haupt's (2015) study increased their reading speed on average by 40 words per minute (wpm) and made a total reading rate increase of $42.8 \%$. Hamersly (2015) found that the TRA increased the fluency and reading rate of students in elementary schools. More recently, Gui, Shang and Chen (2020) found that the TRA significantly improved the reading rate among Chinese EFL students. Previous research also examined the effects of TRA on silent and oral reading (Chang \& Millett, 2015; Salceda, Montesinos, \& Alonso, 2020), on reading simplified and unsimplified texts (Beglar, Hunt, \& Kite, 2012), and on timed reading processes (Hamersly, 2015). Studies also investigated the relationship between reading rate and reading comprehension (Fujita \& Yamashita, 2014) and the relationship between reading speed and types of texts (Yen, 2012). So far, no study has addressed the issue of TRA in EFL mixed-ability classes.

This quantitative intervention study measures the effectiveness of the TRA as a remedial reading activity in mixed-ability classes in the Saudi EFL context. The study aimed to answer the following two questions: 
LTHE 18,1
(1) What is the effect of the TRA on Saudi EFL students' reading rate and reading comprehension in a mixed-ability class?

(2) To what extent is the TRA helpful to mixed-ability Saudi EFL students?

\section{Method}

An interventional pre-test/post-test research design was employed with PY students at a Saudi university. The study sample consisted of one intact reading class $(N=29)$. Prior to the intervention, a pre-test of fast reading was administered among the participants. During the intervention, a dichotomous questionnaire of fast reading strategies was used to detect the participants' use of fast reading strategies. A fast-reading progress chart was also used to closely observe the participants' progress. After the intervention, a post-test was conducted. The intervention lasted for five weeks in the middle of the semester.

\section{Participants and setting}

PY is a remedial pre-college program which aims at bridging the gap between secondary and tertiary education with special attention to raising Saudi students' English language proficiency level and prepare them for academic study. Saudi EFL students join PY with different levels of reading proficiency (Almekhlafy, 2020). Students need to pass PY before they get accepted into the undergraduate major of their choice. Subsequently, PY instructors get mixed-ability students in each classroom.

Several hundred students enroll in PY every semester at the Saudi university where this study took place. These students are divided into sections of 25-40 students. Reading is a course of two-credit hours and four contact hours. This study randomly selected one section of 29 students attending the PY program. All students were Saudi males aged 18-20. The participants had approximately eight years of English learning experience prior to joining the PY program. Some students in the class had attended overseas English courses during the summer holidays, which widened the proficiency gap among the participants even further.

\section{Data collection instruments and procedures}

Four instruments were used for data collection: a pre-test, a post-test, progress charts and a questionnaire. The data were collected before, during and after the intervention. The pre-test was used before the intervention to measure students' reading ability before the start of the intervention. The questionnaire was used before the intervention to identify the wrong fast reading strategies to be addressed during the intervention. The TRA progress charts that tracked students' progress were used during the intervention. The post-test was used after the intervention to measure the effects of TRA on students' reading ability.

The pre-test and post-test consisted of one reading passage followed by eight multiplechoice comprehension questions. The multiple-choice questions had four answer options. The participants needed to apply various reading skills to answer the questions correctly. The reading passages (Pre-test: Form A and Post-test: Form B) were adopted from Reading Power 1 (Mikulecky \& Jeffries, 2005). The two passages were examined in terms of their content and difficulty level to ensure parity as shown in Table 1.

At the beginning of the intervention, a questionnaire was administered. It was adopted from Mikulecky and Jeffries (2005) and aimed to identify the wrong fast reading strategies that students use in order to create a remedial plan for the intervention. The questionnaire consisted of five questions with dichotomous options. Since the purpose of the questionnaire was to generate specific knowledge, the dichotomous form was appropriate (Sauro \& Lewis, 2012). Each question focused on one of the wrong fast reading strategies that may impede 
LTHE 18,1

\section{4}

students' reading speed. Wrong fast reading strategies were highlighted such as reading word by word, using a dictionary while reading, saying every word while reading and writing the Arabic translation above the words on the passage.

To closely observe the participants' progress during the intervention, the TRA progress charts were used which aimed at observing closely the reading rate progress of the participants as the TRA activities were used during the intervention. After each TRA, the participants were given the chance to evaluate their reading rate and reading comprehension and report the time and correct answers. Using these techniques, the researchers generated the progress of the reading rate and reading comprehension for each student.

\section{The intervention}

The intervention designed for this study aimed to improve EFL students' reading rate and reading comprehension as well as to remedy their wrong fast reading strategies. The treatment started with making students aware of the purpose of the TRA in order to increase their interest and involvement in the activities (Anderson \& Nunan, 2008). During the TRA, the students worked individually at their own pace. The instructor encouraged them to read faster, but every student determined what that speed would be. Faster students did not have to wait for slower students, and slower readers were not pressed to read at the same speed as the faster readers. Over a period of five weeks, the TRA exposed students to 15 passages of Reading Power (Mikulecky \& Jeffries, 2005). Each passage was about 200 words long.

At the start of the intervention, the instructor administered the reading pre-test and the questionnaire which encouraged the participants to think about their reading rate and fast reading strategies and raised their curiosity about their reading practices and whether they were using the wrong strategies or not.

During the intervention, the instructor helped students improve their reading rate and comprehension using the TRA and teaching explicit reading strategies. For example, participants were encouraged to break their slow word by word reading habit, and to move their eyes quickly down the passage. They were also encouraged to trust that they would be able to understand the passage without needing to understand every word or sentence in the passage. Moreover, the instructor made them realize that the habit of translating each word into Arabic, their mother tongue, was not a useful reading strategy.

The participants were informed to follow certain guidelines while working on their progress charts. When the participants were ready to begin reading, they wrote the starting time on the line at the top of the reading passage. They used their own watches to record their reading time. As soon as they finished reading a passage, the instructor gave them eight comprehension questions. The questions addressed essential reading comprehension skills. In this step, the participants relied completely on their understanding of the passage and working memory. This was challenging as they were not allowed to go back to the passage, but it encouraged them to read the passage in the next TRA more carefully.

The last step in each session was filling in the progress charts with the reading rate and the number of comprehension questions answered correctly. A visual report of their reading rate and reading comprehension encouraged students to evaluate their progress and set a goal to read faster in the subsequent TRA activities. Each of the 15 TRA activities was implemented in the same way.

\section{Data analysis}

The data were analyzed using SPSS to compare individual variations in the participants' reading rate and reading comprehension before, during and after the intervention of the TRA. Reading rate was measured as the time that a participant took to complete the TRA activity. The word per minute ( $\mathrm{wpm})$ values were recalculated into percentages. The highest reading 
rate (266 wpm) was considered $100 \%$. Reading comprehension was scored out of eight and converted to percentages. These values (reading rate and reading comprehension) were recorded in the TRA progress charts.
EFL students'

reading skills

\section{Results}

The results of the pre-test showed that the students joined the reading class with mixed reading comprehension levels and slow reading rates (see Figure 1).

The wide range of reading ability levels is seen clearly when comparing individual students. One student (s20) was very proficient achieving the highest reading rate and full marks in reading comprehension. Another student (s17) scored less in reading comprehension compared to the reading rate. Some students scored equally low in their reading comprehension and reading rate and others had much higher reading comprehension scores compared to their reading rate.

The analysis of the questionnaire showed that the majority of the students used the wrong reading strategies (see Table 2 ).

In particular, strategy \#4 "You should be able to say every word you read" was the most used reading strategy among the students with $75.9 \%$ admitting using it. Strategies \#2 and \#5, i.e. looking up every word in the dictionary and translating every word in Arabic, were the next most popular strategies with $65.5 \%$ and $62.1 \%$ of the students using them. The majority $(58.6 \%)$ of the students also believed that it is important to read every word in a text in order to understand it (\#1) and that reading fast would impede their understanding (\#3).

A comparison between individual students' use of reading strategies and their pre-test reading rate showed that students with slow reading rates reported using the wrong reading strategies (s3, s6, s17, s22 and s24). In contrast, students with high reading rates (s10, s15 and s20)

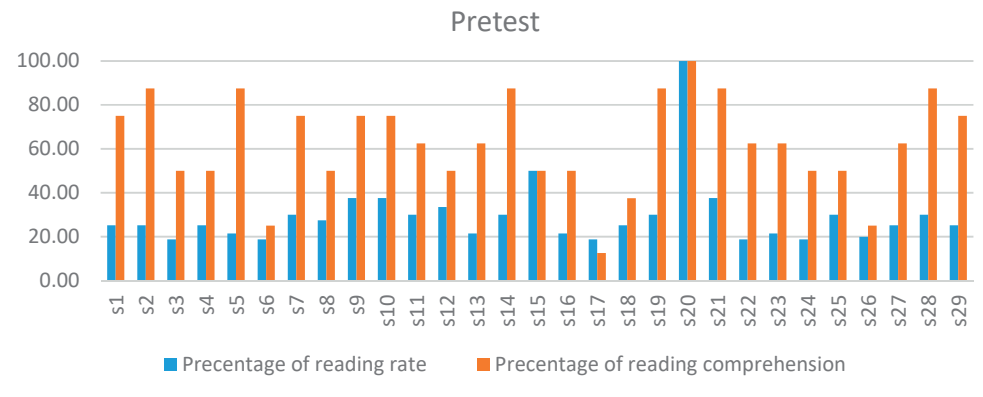

Figure 1.

Pre-test results of students' reading rate and reading comprehension

\begin{tabular}{llcc}
\hline Fast reading strategies & Response & Frequency & Percentage \\
\hline (1) It is important to read every word if you want to understand & Yes & 17 & $58.6 \%$ \\
& No & 12 & $41.4 \%$ \\
(2) You will learn more if you look up every new word in the dictionary & Yes & 19 & $65.5 \%$ \\
& No & 10 & $34.5 \%$ \\
(3) If you read fast, you will not understand & Yes & 17 & $58.6 \%$ \\
& No & 12 & $41.4 \%$ \\
(4) You should be able to say every word you read & Yes & 22 & $75.9 \%$ \\
& No & 7 & $24.1 \%$ \\
(5) You should write the words in your own language above the & Yes & 18 & $62.1 \%$ \\
English words in a book & No & 11 & $37.9 \%$
\end{tabular}

Table 2. Results of the questionnaire on reading strategies used by the students 
LTHE 18,1

\section{6}

reported that they were not using the wrong reading strategies. With this in mind, the TRA intervention started. Students were made aware of using the wrong reading strategies and were encouraged to avoid them while they practiced fast reading activities during the intervention.

After the intervention, the students' reading rates and comprehension scores in the preand post-test were compared using paired samples $t$-tests. In terms of the reading rate, when comparing the students' pre- and post-test results, the TRA was found to have a statistically significant positive effect $(t(28)=-4.652, p=0.000)$ as shown in Table 3.

After five weeks of the TRA intervention, it was found that students had significantly improved their reading. For example, students with very low reading rates at the start of the intervention (s4, s19, s21, s22, s23, s25 and s27) showed significant progress in their reading rates in the post-test.

With regard to students' reading comprehension, it was found that mixed-ability students benefited from the five-week treatment of the TRA because their levels of reading comprehension increased significantly $(t(28)=-4.407, p=0.000)$ (see Table 4).

For example, the students who had very low levels of reading comprehension in the pre-test (s6, s12, s17 and s27) showed significant progress in their reading comprehension in the post-test (see Figures 2 and 3 ).

For 21 of the students both the reading rate and reading comprehension improved. Five students showed improvement only in their reading rate, while two students showed improvement only in their reading comprehension. Only one student (s20) showed a decline in reading rate, while still scoring $100 \%$ in reading comprehension. Overall, the majority of the students improved their reading. The results also showed a few cases where there was no consistency in the improvement in the students' reading rate and reading comprehension. For example, the reading rate of three students (s7, s8 and s20) did not show improvement after the intervention. Similarly, the reading comprehension of four students (s2, s3, s5 and s7) did not show improvement.

Taken together, the results of the analysis showed that after implementing the TRA over a period of five weeks, the students' reading had improved. About $87 \%$ of the students showed improvement either in their reading rate or reading comprehension. The incorporation of the TRA did not only enhance students' reading rate and reading comprehension, but it also remedied their use of wrong reading strategies. The TRA gave students the chance to do the reading activities at their learning pace, taking out all pressure within the learning environment

\section{Paired differences}

\begin{tabular}{|c|c|c|c|c|c|c|c|c|c|}
\hline \multirow{3}{*}{$\begin{array}{l}\text { Table } 3 \text {. } \\
\text { Paired samples } t \text {-test of } \\
\text { pre- and post-test } \\
\text { results of students' } \\
\text { reading rate }\end{array}$} & \multirow{2}{*}{$\begin{array}{l}\text { Reading } \\
\text { rate }\end{array}$} & \multirow{2}{*}{$\begin{array}{c}\text { Mean } \\
\text { difference }\end{array}$} & \multirow{2}{*}{$\begin{array}{c}\text { Std. } \\
\text { deviation }\end{array}$} & \multirow{2}{*}{$\begin{array}{l}\text { Std. error } \\
\text { mean }\end{array}$} & \multicolumn{2}{|c|}{$\begin{array}{l}\text { interval of the } \\
\text { difference }\end{array}$} & \multirow[b]{2}{*}{$t$} & \multirow[b]{2}{*}{ df } & \multirow{2}{*}{$\begin{array}{c}\text { Sig. } \\
\text { (2-tailed) }\end{array}$} \\
\hline & & & & & Lower & Upper & & & \\
\hline & $\begin{array}{l}\text { Pre- and } \\
\text { post-tests }\end{array}$ & -16.76173 & 19.40492 & 3.60340 & -24.14297 & -9.38050 & -4.652 & 28 & 0.000 \\
\hline
\end{tabular}

\section{Table 4.}

\begin{tabular}{|c|c|c|c|c|c|c|c|c|c|}
\hline \multirow{4}{*}{$\begin{array}{l}\text { Table } 4 . \\
\text { Paired samples } t \text {-test of } \\
\text { pre- and post-test } \\
\text { results of students' } \\
\text { reading } \\
\text { comprehension }\end{array}$} & \multirow{3}{*}{$\begin{array}{l}\text { Reading } \\
\text { comprehension }\end{array}$} & \multicolumn{5}{|c|}{ Paired differences } & \multirow[b]{3}{*}{$t$} & \multirow[b]{3}{*}{$\mathrm{df}$} & \multirow{3}{*}{$\begin{array}{c}\text { Sig. } \\
\text { (2-tailed) }\end{array}$} \\
\hline & & Mean & Std. & $\begin{array}{l}\text { Std. } \\
\text { error }\end{array}$ & $\begin{array}{l}95 \% \text { Confic } \\
\text { of the }\end{array}$ & $\begin{array}{l}\text { nce interval } \\
\text { fference }\end{array}$ & & & \\
\hline & & difference & deviation & mean & Lower & Upper & & & \\
\hline & $\begin{array}{l}\text { Pre- and } \\
\text { post-tests }\end{array}$ & -21.98276 & 26.86257 & 4.98825 & -32.20074 & -11.76478 & -4.407 & 28 & 0.000 \\
\hline
\end{tabular}


thus reducing their anxiety and gradually increasing their interest in doing the reading activities.

\section{Discussion}

This study aimed to measure the effects of the TRA on Saudi EFL students' reading rate and reading comprehension and evaluate the appropriateness of the TRA for improving the reading skills of students in mixed-ability classes.

Regarding the effect of the TRA on the reading rate of mixed-ability students, this study revealed that the TRA led to a significant improvement in EFL students' reading rate. This result is in line with previous studies which also found that TRA can improve the reading rate of EFL students (e.g. Chang, 2010; Debbabi et al., 2019; Devana \& Agustina, 2019; Hamersly, 2015; Mahdizadeh \& Aminafshar, 2018; Salceda et al., 2020). While the previous studies revealed a positive effect of the TRA on the reading rate of EFL students in general, the current study provided evidence of the significant positive effect of the TRA on the reading rate of mixed-ability EFL students, therefore making a valuable contribution to the literature.

Similarly, the study proved that mixed-ability students increased their reading comprehension after participating in the TRA intervention over five weeks. This result is similar to the findings of other studies which also found that the TRA was highly effective in developing students' reading comprehension (e.g. Beglar et al., 2012; Chang, 2010; Chang \& Millett, 2015; Debbabi et al., 2019; Devana \& Agustina, 2019). However, the result of the present study contradicts Mahdizadeh and Aminafshar (2018) who found that the TRA did not improve the reading comprehension of EFL Iranian students.

The TRA intervention not only enhanced students' reading skills, but also helped them to remedy their use of wrong reading strategies. This result coincides with Khouyibaba (2015) who found that engaging students with the TRA in the classroom and raising their awareness of the reading strategies they use was one of the most important parts of the learning process. Moreover, the TRA intervention in this study gave students the chance to work individually and evaluate their own progress. Increasing students' responsibility for

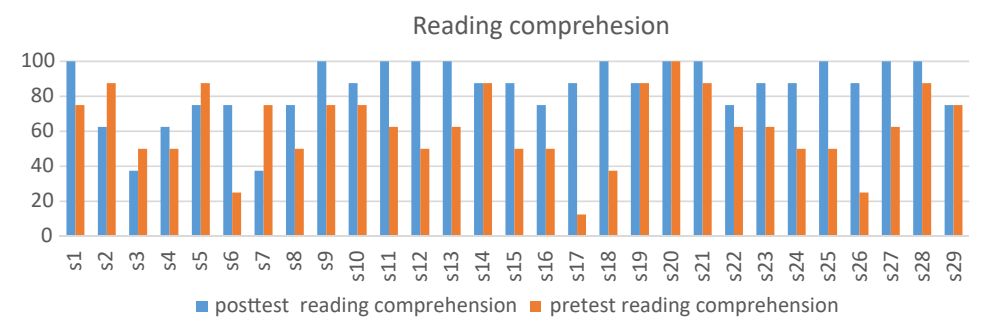

Reading rate

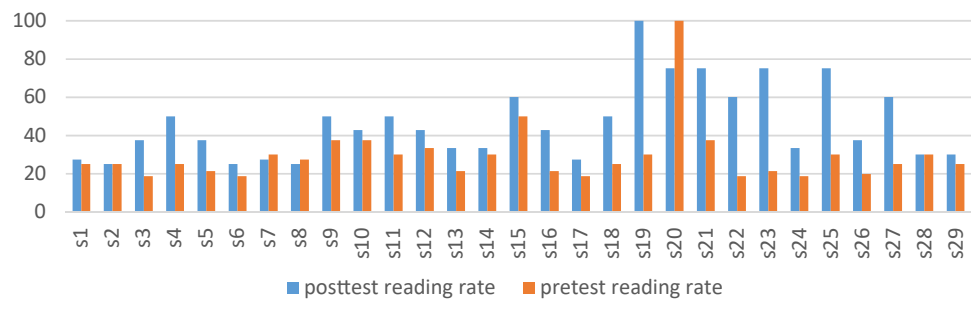

EFL students' reading skills

Figure 2.

Pre- and post-test results of reading comprehension per individual student
Figure 3.

Pre- and post-test results of reading rate per individual student 
LTHE 18,1 their own learning was highly effective in enhancing their classroom participation. This result is in line with Benmassoud and El Madani (2019) who found that individualized remedial teaching can provide adequate improvement even for low achievers.

The inconsistency in the improvement of the reading rate and reading comprehension after the intervention in some of the students is understandable. Reading rate and reading comprehension do not always improve in tandem. For example, Fujita and Yamashita (2014) found a weak relationship between reading rate and reading comprehension among Japanese EFL students. In an earlier study, Yen (2012) found that most of the Vietnamese EFL participants increased their reading rate without increasing their reading comprehension. At the end of the day, no two students are alike, so an activity that works well for one student may not work the same way with another (Treko, 2013). It is also possible that for some students, especially the low achievers, the five-week TRA intervention may not have been long enough for them to show significant improvement. A longer intervention would have increased the amount of reading students had to do and this might have been enough to help low achievers to improve. Chang (2012) found that increasing the reading amount for the TRA group improved their reading rates and their reading comprehension.

As for the intervention, it was a challenge at the beginning to convince the students to overcome their use of the wrong fast reading strategies. Most of them did not differentiate between oral and silent reading. This might be due to their oral cultural background (Al-Khresheh, 2020). Another obstacle was that students were used to using a dictionary to translate every word into their mother tongue, Arabic. This hindered their reading rate. Another problematic issue that had to be overcome was the conception of "understanding" which is highly valued in academic contexts. These students believed that fast reading impeded their understanding, and that word-by-word reading was the solution. It took time and hard effort during the intervention to make these students aware of their wrong reading strategies and convince them to approach reading in different ways. If anything, the intervention helped students pay attention to the reading strategies they use and raised their awareness of things they can do to improve their reading.

\section{Conclusion}

This study aimed to measure the effect of incorporating the TRA in EFL reading classes to enhance mixed-ability students' reading rate and reading comprehension. A total of $29 \mathrm{EFL}$ students attending a PY program at a Saudi university participated in a five-week TRA intervention. Results revealed that the TRA had a statistically significant positive effect on students' reading rate and reading comprehension. Based on the study findings, the TRA appears to be an appropriate instructional approach for mixed-ability classes because students can truly work at their pace, determine their own reading rate and assess their own level of reading comprehension. With such features, the TRA presents a useful remedial activity for a challenging context like mixed-ability EFL classes. The results of the present study have significant implications for the PY program at Saudi universities. Mixed-ability EFL reading classes need to be approached with flexible teaching and learning activities such as the TRA. Educators need to minimize the gap between slow learners and high achievers by introducing remedial programs such as the TRA.

The current study is not devoid of limitations. The study used quantitative methods for data collection. Qualitative methods like interviews and observation would help to investigate in depth participants' perspectives and views towards the TRA intervention. Furthermore, future research can investigate the specific factors that influence the reading rates and levels of reading comprehension when practicing the TRA in mixed-ability classes. Finally, the study was done with a relatively small group of male Saudi students. It would be 
useful to replicate this study with female students and a larger sample in order to boost the generalizability of the results.

Although limited in its scope, the current study showed that a successful implementation of the TRA is the key factor for developing the reading skills of mixed-ability EFL students. Moreover, remedial activities like the TRA make EFL students more confident and responsible for their own learning and put them on the path to becoming independent learners.
EFL students' reading skills

\section{References}

Al-Khresheh, M. H. (2020). The impact of cultural background on listening comprehension of Saudi EFL students. Arab World English Journal, 11(3), 349-371, doi: 10.24093/awej/vol11no3.22.

Al-Mekhlafi, A., \& Nagaratnam, R. P. (2012). From firm ground to shifting sands: Issues IN adopting learner-centred ESL/EFL pedagogy. English Teacher, 41(1), Available from: http://journals. melta.org.my/index.php/tet/article/view/246.

Al-Shammakhi, F., \& Al-Humaidi, S. (2015). Challenges facing EFL teachers in mixed ability classes and strategies used to overcome them. World Journal of English Language, 5(3), 33.

Al-Shehri, S. (2017). A developmental paradigm for English language instruction at preparatory year programs. Arab World English Journal, 8, doi: 10.24093/awej/vol8no3.28.

Al-Subaiei, M. S. (2017). Challenges in mixed ability classes and strategies utilized by ELI teachers to cope with them. English Language Teaching, 10(6), 182-189, doi: 10.5539/elt.v10n6p182.

Almekhlafy, S. S. A. (2017). Remediation in EFL challenging context. Journal of Modern Education Review, 7(12), 855-863, Available from: https://scholar.google.com/scholar_lookup?title=Remediation \%20in $\% 20 \mathrm{EFL} \% 20$ challening $\% 20$ context\&publication_year $=2017 \&$ author $=$ S.S. $\% 20$ Almekhlafy.

Almekhlafy, S. S. A., \& Alqahtani, A. A. J. (2020). The visual memory development technique: A remedial and pre-reading activity to enhance EFL learners' motivation. Heliyon, 6(3), e03627, doi: 10.1016/j.heliyon.2020.e03627.

Anderson, N. J., \& Nunan, D. (2008). Practical English language teaching. Reading: McGraw-Hill ESL/ELT.

Beglar, D., Hunt, A., \& Kite, Y. (2012). The effect of pleasure reading on Japanese university EFL learners' reading rates. Language Learning, 62(3), 665-703.

Benmassoud, J., \& El Madani, M. E. M. (2019). The teaching multilevel classrooms in Morocco: The case study of high schools in Meknes. GPH - International Journal of Educational Research, 2(3), 1-14.

Bolli, T., Renold, U., \& Wörter, M. (2018). Vertical educational diversity and innovation performance. Economics of Innovation and New Technology, 27(2), 107-131, doi: 10.1080/10438599.2017.1314075.

Butterworth, D. B. (2010). Placing Gifted Students At-risk in Mixed-Ability Classrooms: A Sequential Mixed Methods Analysis. ProQuest LLC, Ed.D. Dissertation, ERIC Number ED520442, Walden University.

Chang, A. (2010). The effect of a timed reading activity on EFL learners: Speed, comprehension, and perceptions. Reading in a Foreign Language, 22(2), 284-303.

Chang, A. (2012). Improving reading rate activities for EFL students: Timed reading and repeated oral reading, Reading in a Foreign Language, 24, 56-83.

Chang, A. C. S., \& Millett, S. (2015). Improving reading rates and comprehension through audioassisted extensive reading for beginner learners. System, 52, 91-102, doi: 10.1016/j.system.2015. 05.003 .

Cheng, C. M. (2014). Individual differences: How remedial teaching transforms low-achievers when learning English. Journal of Modern Education Review, 4(11), 859-877, doi: 10.15341/jmer(21557993)/11.04.2014/001.

Debbabi, A. S., Alsheyokh, R. S. M., Al Kous, R. K. M., Maimoun, S. A. A., Humiedan, M. M., \& Mansoor, M. (2019). A study of Saudi English foreign language (EFL) learners: Impact of timed 
LTHE 18,1

reading on learners' reading speed and level of comprehension. International Journal of Applied Engineering Research, 14(19), 3778-3782.

Devana, T., \& Agustina, A. (2019). Effect of screen text in improving students' reading rate and reading comprehension. Jambi-English Langauage Teaching Journal, 4(2), 1-79.

Fujita, K., \& Yamashita, J. (2014). The relations and comparisons between reading comprehension and reading rate of Japanese high school EFL learners. The Reading Matrix, 14(2), 34-49.

Gui, M., Shang, Y., and Chen, X. (2020). Effect of timed reading on Chinese undergraduates' EFL reading rates: Mixed-method analyses. Reading in a Foreign Language, 32(2), 104-121, Available from: http://hdl.handle.net/10125/67376.

Hamersly, T. (2015). How timed reading improves students in the classroom. Journal on Best Teaching Practices, 2(2), 16-17.

Harmer, J. (2015). The Practice of English Language Teaching. Harlow: Pearson Education.

Haupt, J. (2015). The use of a computer-based reading rate development program on pre-university intermediate level ESL learners' reading speeds. Reading Matrix: An International Online Journal, 15(1), 1-14.

Hernandez, T. (2012), "Teach to the Middle": A Double Case Study of Two Multilevel EFL Classes in the Middle East. MA TESOL Collection, In Paper 544, SIT Graduate Institute, Available from: https:// digitalcollections.sit.edu/ipp_collection/544.

Khamdamovna, M. U., \& Karimovna, K. S. (2020). The problem of teaching English in mixed ability classes. ДостиЖения науки и образования, 5(59), 40-41.

Khouyibaba, S. (2015). Teaching remedial courses: Challenges and teaching philosophy. ProcediaSocial and Behavioral Sciences, 186, 927-931, doi: 10.1016/j.sbspro.2015.04.004.

Mahdizadeh, M., \& Aminafshar, N. (2018). The impact of timed reading activity on Iranian EFL learners reading speed, comprehension, and attitudes at intermediate level. Advances in Language and Literary Studies, 9(5), 11-16, doi: 10.7575/aiac.alls.v.9n.5p.11.

Mathews-Aydinli, J., \& Van Horne, R. (2006). Promoting the success of multilevel ESL classes: What teachers and administrators can do. CAELA Brief, 2, 1-5.

McLean, S., \& Rouault, G. (2017). The effectiveness and efficiency of extensive reading at developing reading rates. System, 70, 92-106, doi: 10.1016/j.system.2017.09.003.

McMillan, B., \& Joyce, P. (2011). Teacher perspectives on student placement in university EFL programs. Journal of NELTA, 16(1-2), 70-81, doi: 10.3126/nelta.v16i1-2.6131.

Mikulecky, B. S., \& Jeffries, L. (2005). Reading Power 1: Reading for Pleasure, Comprehension Skills, Thinking Skills, Reading Faster (3rd ed.). White Plains, NY: Pearson Education.

Naddafi, F., Vosoughi, M., \& Kowsary, M. A. (2019). Inspecting mixed-ability group challenges within Iranian EFL public high schools: An exploratory study Fatemeh. International Journal of Foreign Language Teaching and Research, 7(27), 125-145.

Salceda, J. C. R., Montesinos, M. M. T., \& Alonso, G. A. (2020). Reading rate in Spanish-speaking students: A meta-analysis. Revista de Psicodidáctica (English Edition), 25(2), 158-165, doi:10. 1016/j.psicoe.2020.01.001.

Sauro, J., \& Lewis, J. R. (2012). Quantifying the User Experience: Practical Statistics for User Research. Burlington, MA: Morgan-Kaufmann, doi: 10.1016/b978-0-12-384968-7.00002-3.

Scrivener, J. (2012). Classroom Management Technique. Cambridge: Cambridge University Press.

Suk, N. (2017). The effects of extensive reading on reading comprehension, reading rate, and vocabulary acquisition. Reading Research Quarterly, 52(1), 73-89, doi: 10.1002/rrq.152.

Tomlinson, C. A. (2014). Differentiated Classroom: Responding to the Needs of all Learners. ASCD.

Treko, N. (2013). The big challenge: Teaching large multi-level classes. Academic Journal of Interdisciplinary Studies, 2(4), 243, doi: 10.5901/ajis.2012.v2n4p243.

Valentic, D. (2005). ELT in multi-level classes. Hupe Newsletter, 2(3), 47-53. 
Wright, T. (2012). How to be a Brilliant English Teacher. London: Routledge.

Wróblewski, B., \& Majerová, M. (2019). Teaching strategies and techniques in mixed-ability classes. CASALC Review, 9(2), 31, doi: 10.5917/CASALC2019-2-3.

Yen, T. T. N. (2012). The effects of a speed reading course and speed transfer to other types of texts. RELC Journal, 43(1), 23-37, doi: 10.1177/0033688212439996.

Yunusova, A. A. (2019). Strategies for teaching in mixed ability classes. МеЖдународныии академический вестник, 1, 34-35.

Zakarneh, B., Al-Ramahi, N., \& Mahmoud, M. (2020). Challenges of teaching English language classes of slow and fast learners in the United Arab Emirates universities. International Journal of Higher Education, 9(1), 256-269, doi: 10.5430/ijhe.v9n1p256.

\section{Further reading}

Creswell, J. W. (2014). A Concise Introduction to Mixed Methods Research. University of NebraskaLincoln: Sage Publications.

Kramer, B., \& McLean, S. (2019). L2 reading rate and word length: The necessity of character-based measurement, Reading in a Foreign Language, 31(2), 201-225.

Morlini, I., Stella, G., \& Scorza, M. (2014). A new procedure to measure children's reading speed and accuracy in Italian. Dyslexia, 20(1), 54-73, doi: 10.1002/dys.1462.

Rogers, J., \& Révész, A. (2020). Experimental and quasi-experimental designs. In The Routledge Handbook of Research Methods in Applied Linguistics. New York: Routledge, doi: 10.4324/ 9780367824471-12.

Schoonenboom, J. (2016). The multilevel mixed intact group analysis: A mixed method to seek, detect, describe, and explain differences among intact groups. Journal of Mixed Methods Research, 10(2), 129-146.

\section{Corresponding author}

Sultan Saleh Ahmed Almekhlafy can be contacted at: alameer.almekhlafy@gmail.com

For instructions on how to order reprints of this article, please visit our website:

www.emeraldgrouppublishing.com/licensing/reprints.htm

Or contact us for further details: permissions@emeraldinsight.com 